\title{
An Investigation of the Consciousness Energy Healing Therapy on Physicochemical and Thermal Properties of Silver Sulfadiazine
}

\author{
Dahryn Trivedii ${ }^{1}$, Mahendra Kumar Trivedi ${ }^{1}$, Alice Branton ${ }^{1}$, Gopal Nayak ${ }^{1}$ and Snehasis Jana ${ }^{2 *}$ \\ ${ }^{1}$ Trivedi Global, Inc., Henderson, USA \\ ${ }^{2}$ Trivedi Science Research Laboratory Pvt. Ltd, India
}

Submission: September 04, 2018; Published: October 23, 2018

*Corresponding author: Snehasis Jana, Trivedi Science Research Laboratory Pvt. Ltd., Bhopal, India. Tel: +91-022-25811234;

Email: publication@trivedieffect.com

\begin{abstract}
Silver sulfadiazine is a topical sulfa drug antibiotic that is used by burn patients to prevent the bacterial infection. This study was aimed to analyze the impact of the Trivedi Effect ${ }^{\circledR}$ on the physicochemical and thermal properties of silver sulfadiazine with the help of various analytical techniques. The silver sulfadiazine sample was divided into the control and treated parts; where, no Biofield Treatment was provided to the control part, while the treated part received the Biofield Treatment remotely by a renowned Biofield Energy Healer, Dahryn Trivedi. The PXRD peak intensities and the crystallite sizes were significantly altered ranging from $-75.25 \%$ to $31.21 \%$ and $-8.80 \%$ to $192.76 \%$ respectively, along with $64.06 \%$ increase in the average crystallite size of the treated sample than the control sample. The particle sizes were decreased by $1.60 \%$ $\left(\mathrm{d}_{10}\right), 2.30 \%\left(\mathrm{~d}_{50}\right), 2.06 \%\left(\mathrm{~d}_{90}\right)$, and $4.40 \%[\mathrm{D}(4,3)]$; therefore, the surface area was increased by $2.61 \%$ in the treated sample in contrast to the control sample. The latent heat of fusion and decomposition of the treated sample were significantly altered by $-21.52 \%$ and $32.03 \%$, respectively, compared to the control sample. Additionally, the total weight loss was reduced by $1.86 \%$; however, the residue amount was increased by $2.88 \%$ in the treated sample compared with the control sample. Hence, the Biofield Treatment might be considered as a novel approach to generate a new polymorph of silver sulfadiazine that is more soluble, bioavailable, and thermally stable, which could be useful in designing a novel pharmaceutical formulation for the better therapeutic response against various type of bacterial disease.
\end{abstract}

Keywords: Silver sulfadiazine; Consciousness Energy Healing Treatment; The Trivedi Effect ${ }^{\circledR}$; Complementary and Alternative Medicine; PXRD Particle size; TGA/DTG

\section{Introduction}

Silver sulfadiazine is a drug belongs to the sulfa drug antibiotics class [1]. It is mainly used to prevent and treat wound infections in burn patients by preventing the growth of infectious bacteria on the open wound [2]. It also helps in decreasing the risk of bacterial growth on the surrounding skin and blood and prevents the serious blood infection such as sepsis [3]. Silver sulfadiazine is a broad spectrum drug that mainly acts on the gram-negative bacteria. Moreover, it shows good tolerance and low toxicity in patients; thus, also used for third \& fourth-degree burns [4]. The bactericidal activity of silver sulfadiazine is takes place on the cell membrane and cell wall of the bacteria. For this, the silver ions present in the drug, catalyse the disulphide bonds formation, which causes change in the protein structure and thereby inactivates the thiol-containing enzymes [5]. Also, the silver ions may act by intercalating the DNA that interferes with the process of replication and transcription of the bacteria [6]. The sulfadiazine part of drug acts by inhibiting the bacterial dihydropteroate synthase, thereby disrupting the folic acid metabolism and DNA synthesis in bacteria $[7,8]$.
The silver sulfadiazine shows its effect by reacting at a slow and steady rate with serum and other body fluids, which allows only the slow and sustained delivery of silver ions into the wound area. However, it reduces the bioavailability of the drug within the body [9]. Also, the studies reported the poor solubility of the drug and its limited penetration through the intact skin [10]. Thus, the study of its physicochemical properties is done to improve its dissolution and absorption parameters in the formulation. The Biofield Energy Healing Treatment (the Trivedi Effect ${ }^{\circledR}$ ) has been known for its considerable effect on the physicochemical and thermal behaviour of many compounds [11-14], that may also affect the solubility and bioavailability profile of both the pharmaceuticals and nutraceuticals.

A unique energy (infinite, para-dimensional electromagnetic field) is possessed by every living organism that surrounds their body and known as the "Biofield Energy". The Trivedi Effect ${ }^{\circledR}$ is a phenomenon that is established as; a person can harness the inherently intelligent energy and transmit it anywhere on the planet through the possible mediation of neutrinos [15]. The 
National Institutes of Health/National Center for Complementary and Alternative Medicine (NIH/NCCAM) also recommended the Energy therapies and included them under the category of Complementary and Alternative Medicine (CAM) along with other therapies, medicines and practices such as naturopathy, homeopathy, traditional Chinese herbs and medicines, aromatherapy, Ayurvedic medicine, Qi Gong, Tai Chi, Reiki, hypnotherapy, yoga, chiropractic/osteopathic manipulation, meditation, massage, relaxation techniques, guided imagery, healing touch, acupuncture, acupressure, Rolfing structural integration, mindfulness, cranial sacral therapy and applied prayer [16]. Biofield (Putative Energy Fields) based Energy Healing Therapies have been known for their significant outcomes against various disease conditions with several advantages and therefore, accepted by most of the U.S. population [17].

Besides, several studies reported the astounding capability of the Trivedi Effect ${ }^{\circledR}$-Consciousness Energy Healing Treatment for altering the characteristics of the non-living materials and living object(s), such as metals and ceramic $[18,19]$, nutraceuticals/ pharmaceuticals [20-23], and organic compounds [24,25]. It is also reported for its unique impact in the field of biotechnology [26], microbiology [27-29], skin health [30], livestock [31], and crops $[32,33]$. Hence, in this study, the impact of the Trivedi Effect $^{\circledR}{ }_{\text {- }}$ Consciousness Energy Healing Treatment on silver sulfadiazine was evaluated with respect to the physicochemical and thermal properties by using the various analytical techniques such as, powder X-ray diffraction (PXRD), particle size analysis (PSA), differential scanning calorimetry (DSC), and thermogravimetric analysis (TGA)/differential thermogravimetric analysis (DTG).

\section{Materials and Methods}

\section{Chemicals and Reagents}

The silver sulfadiazine was purchased from Tokyo Chemical Industry Co., Ltd., Japan. All other chemicals used during the experiments were of analytical grade available in India.

\section{Consciousness Energy Healing Treatment Strategies}

The silver sulfadiazine test sample was divided into two parts. One part was considered as the control sample (no Biofield Energy Treatment was provided). Consequently, the second part of silver sulfadiazine was treated with the Trivedi Effect ${ }^{\circledR}$-Energy of Consciousness Healing Treatment remotely under standard laboratory conditions for 3 minutes known as the Trivedi Effect ${ }^{\circledR}$ Treated or the Biofield Energy Treated silver sulfadiazine sample. This Biofield Energy Treatment was provided through the healer's unique energy transmission process by the renowned Biofield Energy Healer, Dahryn Trivedi, USA, to one part of the test sample. Further, the control sample was treated with a "sham" healer for comparison purposes. The "sham" healer did not have any knowledge about the Biofield Energy Treatment. After treatment, the Biofield Energy Treated and untreated sample were both kept in sealed conditions and characterized using PXRD, PSA, DSC, and TGA/DTG techniques.

\section{Characterization}

\section{Powder X-ray Diffraction (PXRD) Analysis}

The PXRD analysis of silver sulfadiazine was performed with the help of RigakuMiniFlex-II Desktop X-ray diffractometer (Japan) $[34,35]$. The $\mathrm{Cu}$ Ko radiation source tube output voltage used was $30 \mathrm{kV}$ and tube output current $15 \mathrm{~mA}$. Scans were performed at room temperature. The average size of individual crystallites was calculated from XRD data using the Scherrer's formula (1):

$$
\mathrm{G}=\mathrm{k} \lambda / \beta \cos \theta
$$

Where $\mathrm{k}$ is the equipment constant (0.94), $\mathrm{G}$ is the crystallite size in $\mathrm{nm}, \lambda$ is the radiation wavelength $(0.154056 \mathrm{~nm}$ for $\mathrm{K} \alpha 1$ emission), $\beta$ is the full-width at half maximum (FWHM), and $\theta$ is the Bragg angle [36]. The percent change in crystallite size (G) of silver sulfadiazine was calculated using the following equation 2 :

$$
\% \text { change in crystallite size }=\frac{\left[G_{\text {Treated }}-G_{\text {Control }}\right]}{G_{\text {Control }}} \times 100(2)
$$

Where $\mathrm{G}_{\text {Control }}$ and $\mathrm{G}_{\text {Treated }}$ are the crystallite size of the control and the Biofield Energy Treated samples, respectively.

\section{Particle Size Analysis (PSA)}

The particle size analysis of silver sulfadiazine was conducted on Malvern Mastersizer 2000, from the UK with a detection range between $0.01 \mu \mathrm{m}$ to $3000 \mu \mathrm{m}$ using wet method [37,38]. The sample unit (Hydro MV) was filled with a dispersant medium (sunflower oil) and the stirrer operated at $2500 \mathrm{rpm}$. The PSA analysis of silver sulfadiazine was performed to obtain the average particle size distribution. Where, $d(0.1) \mu \mathrm{m}, d(0.5) \mu \mathrm{m}$, $\mathrm{d}(0.9) \mu \mathrm{m}$ represent particle diameter corresponding to $10 \%$, $50 \%$, and $90 \%$ of the cumulative distribution. D $(4,3)$ represents the average mass-volume diameter, and SSA is the specific surface area $\left(\mathrm{m}^{2} / \mathrm{g}\right)$. The calculations were done by using software Mastersizer Ver. 5.54.

The percent change in particle size (d) at below $10 \%$ level $\left(d_{10}\right), 50 \%$ level $\left(d_{50}\right), 90 \%$ level $\left(d_{90}\right)$, and $D(4,3)$ was calculated using the following equation 3 :

$$
\% \text { change in particle size }=\frac{\left[\mathrm{d}_{\text {Treated }}-\mathrm{d}_{\text {Control }}\right]}{\mathrm{d}_{\text {Control }}} \times 100 \text { (3) }
$$

Where $\mathrm{d}_{\text {Control }}$ and $\mathrm{d}_{\text {Treated }}$ are the particle size $(\mu \mathrm{m})$ for at below $10 \%$ level $\left(d_{10}\right), 50 \%$ level $\left(d_{50}\right)$, and $90 \%$ level $\left(d_{90}\right)$ of the control and the Biofield Energy Treated samples, respectively.

The percent change in surface area (S) was calculated using the following equation 4 :

$$
\% \text { change in surface area }=\frac{\left[\mathrm{S}_{\text {Treated }}-\mathrm{S}_{\text {Control }}\right]}{\mathrm{S}_{\text {Control }}} \times 100
$$

Where $\mathrm{S}_{\text {Control }}$ and $\mathrm{S}_{\text {Treated }}$ are the surface area of the control and the Biofield Energy Treated silver sulfadiazine, respectively. 


\section{Differential Scanning Calorimetry (DSC)}

The DSC analysis of silver sulfadiazine was performed with the help of DSC Q200, TA instruments. Sample of 1-5 mg was loaded to the aluminium sample pan at a heating rate of $10^{\circ} \mathrm{C} /$ min from $30^{\circ} \mathrm{C}$ to $350^{\circ} \mathrm{C}[37,38]$. The $\%$ change in melting point (T) was calculated using the following equation 5 :

$$
\% \text { change in melting point }=\frac{\left[\mathrm{T}_{\text {Treated }}-\mathrm{T}_{\text {Control }}\right]}{\mathrm{T}_{\text {Control }}} \times 100 \text { (5) }
$$

Where $\mathrm{T}_{\text {Control }}$ and $\mathrm{T}_{\text {Treated }}$ are the melting point of the control and Biofield Energy Treated samples, respectively. The percent change in the latent heat of fusion $(\Delta \mathrm{H})$ was calculated using the following equation 6 :

$\%$ change in the latent heat of fusion $=\frac{\left[\Delta \mathrm{H}_{\text {Treated }}-\Delta \mathrm{H}_{\text {Control }}\right]}{\Delta \mathrm{H}_{\text {Control }}} \times 100(6)$

Where $\Delta \mathrm{H}_{\text {Control }}$ and $\Delta \mathrm{H}_{\text {Treated }}$ are the latent heat of fusion of the control and Biofield Energy Treated silver sulfadiazine, respectively.

\section{Thermal Gravimetric Analysis (TGA)/ Differential thermogravimetric analysis (DTG)}

TGA/DTG thermograms of silver sulfadiazine were obtained with the help of TGA Q50 TA instruments. Sample of $5 \mathrm{mg}$ was loaded to the platinum crucible at a heating rate of $10^{\circ} \mathrm{C} / \mathrm{min}$ from $25^{\circ} \mathrm{C}$ to $1000^{\circ} \mathrm{C}$ with the recent literature $[37,38]$. The $\%$ change in weight loss $(\mathrm{W})$ was calculated using the following equation 7 :

$$
\% \text { change in weight loss }=\frac{\left[\mathrm{W}_{\text {Treated }}-\mathrm{W}_{\text {Control }}\right]}{\mathrm{W}_{\text {Control }}} \times 100 \text { (7) }
$$

Where $\mathrm{W}_{\text {Control }}$ and $\mathrm{W}_{\text {Treated }}$ are the weight loss of the control and the Biofield Energy Treated silver sulfadiazine, respectively. The \% change in maximum thermal degradation temperature $\left(\mathrm{T}_{\max }\right)(\mathrm{M})$ was calculated using the following equation 8:

$$
\text { \% change in Tmax }(M)=\frac{\left[\mathrm{M}_{\text {Treated }}-\mathrm{M}_{\text {Control }}\right]}{\mathrm{M}_{\text {Control }}} \times 100 \text { (8) }
$$

Where $\mathrm{M}_{\text {Control }}$ and $\mathrm{M}_{\text {Treated }}$ are the $\mathrm{T}_{\max }$ values of the control and the Biofield Energy Treated silver sulfadiazine, respectively.

\section{Results and Discussion}

\section{Powder X-ray Diffraction (PXRD) Analysis}

The diffractograms of the control and the Biofield Energy Treated sample showed peaks of high intensity and narrow base width that are the properties of crystalline materials (Figure 1). However, the Bragg's angles of the characteristic peaks of the Biofield Energy Treated sample, including the highest intensity peak $\left(2 \theta=10.11^{\circ}\right)$, were observed to differ from the Bragg's angles of the control sample (highest intensity peak at $2 \theta=10.32^{\circ}$ ). It reveals some alterations in the crystalline structure of the Biofield Energy Treated sample after the Biofield energy Treatment. Moreover, the Biofield Energy Treated silver sulfadiazine also showed alterations in the intensities of the characteristic peaks and their corresponding crystallite sizes ranging from $-75.25 \%$ to $31.21 \%$ and $-8.80 \%$ to $192.76 \%$, respectively (Table 1 ). Besides, the huge alteration was observed in the average crystallite size of the Biofield Energy Treated sample (455.14 nm), which was significantly increased by $64.06 \%$ compared with the control sample $(277.43 \mathrm{~nm})$.

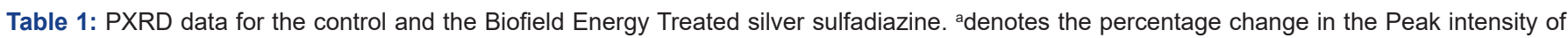

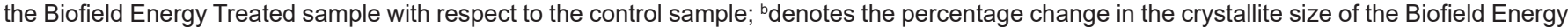
Treated sample with respect to the control sample.

\begin{tabular}{|c|c|c|c|c|c|c|c|c|}
\hline \multirow{2}{*}{ Entry No. } & \multicolumn{2}{|c|}{ Bragg angle $\left({ }^{\circ} \mathbf{2} \Theta\right)$} & \multicolumn{3}{|c|}{ Peak Intensity (\%) } & \multicolumn{3}{c|}{ Crystallite size (G, nm) } \\
\cline { 2 - 9 } & Control & Treated & Control & Treated & \% change ${ }^{\mathbf{a}}$ & Control & Treated & \% change ${ }^{\mathbf{b}}$ \\
\hline 1 & 8.82 & 8.67 & 157 & 206 & 31.21 & 214 & 515 & 140.65 \\
\hline 2 & 10.32 & 10.11 & 2179 & 1094 & -49.79 & 221 & 647 & 192.76 \\
\hline 3 & 13.09 & 12.88 & 139 & 54 & -61.15 & 284 & 448 & 57.75 \\
\hline 4 & 16.15 & 15.99 & 179 & 77 & -56.98 & 321 & 485 & 51.09 \\
\hline 5 & 18.68 & 18.36 & 497 & 158 & -68.21 & 288 & 590 & 104.86 \\
\hline 6 & 19.96 & 19.74 & 202 & 81 & -59.90 & 221 & 371 & 67.87 \\
\hline 7 & 20.67 & 20.54 & 195 & 70 & -64.10 & 267 & 312 & 16.85 \\
\hline 8 & 21.70 & 21.43 & 202 & 50 & -75.25 & 326 & 461 & 41.41 \\
\hline 9 & 23.14 & 22.95 & 308 & 90 & -70.78 & 284 & 447 & 57.39 \\
\hline 10 & 23.69 & 23.56 & 160 & 58 & -63.75 & 432 & 394 & -8.80 \\
\hline 11 & 24.39 & 24.18 & 309 & 104 & -66.34 & 276 & 366 & 32.61 \\
\hline 12 & 29.78 & 29.46 & 152 & 51 & -66.45 & 266 & 581 & 118.42 \\
\hline 13 & 37.62 & 37.31 & 120 & 102 & -15.00 & 153 & 183 & 19.61 \\
\hline 14 & 38.65 & 38.38 & 96 & 73 & -23.96 & 331 & 572 & 72.81 \\
\hline
\end{tabular}


In crystalline compounds, the changes in peak intensity corresponding to each diffraction face indicates the alteration in the crystal morphology [39], and the alterations in the overall PXRD pattern are the proof of polymorphic transitions taking place in drug $[40,41]$. Hence, such significant changes in the Bragg's angles of the peaks, their intensities, and the corresponding crystallite sizes indicate the altered morphology and polymorphic transitions of the Biofield Energy Treated silver sulfadiazine crystals after the Biofield Energy Treatment, compared with the untreated sample. Moreover, the variation in the polymorphic forms of pharmaceuticals is known for its impact on the drug performance in terms of its therapeutic efficacy, bioavailability, and toxicity $[42,43]$. Thus, it could be presumed that the Trivedi Effect $^{\circledR}$ Treated sample might offer a better therapeutic response in comparison to the untreated silver sulfadiazine.

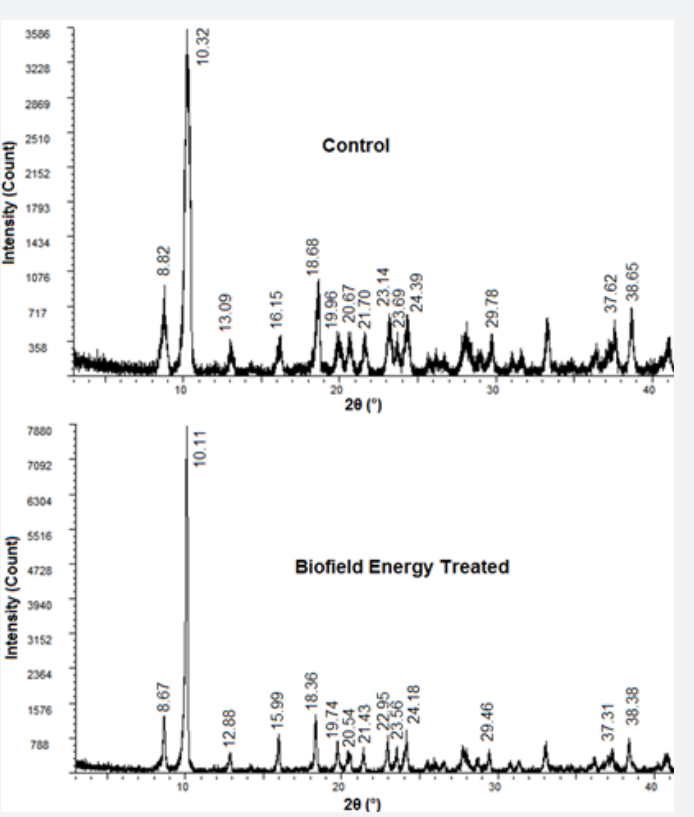

Figure 1: PXRD diffractograms of the control and the Biofield Energy Treated silver sulfadiazine.

\section{Particle Size Analysis (PSA)}

Table 2: Particle size distribution of the control and the Biofield Energy Treated silver sulfadiazine. $\mathrm{d}_{10}, \mathrm{~d}_{50}$, and $\mathrm{d}_{90}$ : particle diameter corresponding to $10 \%, 50 \%$, and $90 \%$ of the cumulative distribution, D $(4,3)$ : the average mass-volume diameter, and SSA: the specific surface area. *denotes the percentage change in the Particle size distribution of the Biofield Energy Treated sample with respect to the control sample.

\begin{tabular}{|c|c|c|c|c|c|}
\hline Parameter & $\begin{array}{c}\mathbf{d}_{\mathbf{1 0}} \\
(\boldsymbol{\mu \mathbf { m } )}\end{array}$ & $\begin{array}{c}\mathbf{d}_{\mathbf{5 0}} \\
(\boldsymbol{\mu \mathrm { m } )})\end{array}$ & $\begin{array}{c}\mathbf{d}_{\mathbf{9 0}} \\
(\boldsymbol{\mu \mathbf { m } )})\end{array}$ & $\begin{array}{c}\mathbf{D}(\mathbf{4}, \mathbf{3}) \\
(\boldsymbol{\mu \mathbf { m } )}\end{array}$ & $\mathbf{S S A}\left(\mathbf{m}^{\mathbf{2}} / \mathbf{g}\right)$ \\
\hline Control & 7.50 & 30.82 & 93.61 & 44.32 & 0.537 \\
\hline $\begin{array}{c}\text { Biofield } \\
\text { Treated }\end{array}$ & 7.38 & 30.11 & 91.68 & 42.37 & 0.551 \\
\hline $\begin{array}{c}\text { Percent } \\
\text { change* } \%)\end{array}$ & -1.60 & -2.30 & -2.06 & -4.40 & 2.61 \\
\hline
\end{tabular}

The particle size distribution analysis of the control and the Biofield Energy Treated samples were done (Table 2) to see any changes due to the Biofield Energy Treatment on the silver sulfadiazine. The data showed that the particle size values of the Biofield Energy Treated sample at $d_{10}, d_{50}, d_{90}$, and D $(4,3)$ were reduced by $1.60 \%, 2.30 \%, 2.06 \%$, and $4.40 \%$, respectively compared to the control silver sulfadiazine. Therefore, the specific surface area (SSA) of the Biofield Energy Treated sample $\left(0.551 \mathrm{~m}^{2} / \mathrm{g}\right)$ was increased by $2.61 \%$ in comparison to the SSA of the control sample $\left(0.537 \mathrm{~m}^{2} / \mathrm{g}\right)$. Thus, it could be presumed the Biofield Energy Healing Treatment might reduce the particle size of silver sulfadiazine by acting as an external force [44]. The reduction in particle size is known to improve the solubility and absorption, and ultimately the bioavailability in the body by increasing the surface area of the drug [45-47]. Hence, the decreased particle size and increased surface area of the Biofield Energy Treated silver sulfadiazine after the Biofield Energy Treatment might be considered as the improved bioavailability profile of drug compared with the untreated sample.

\section{Differential Scanning Calorimetry (DSC) Analysis}

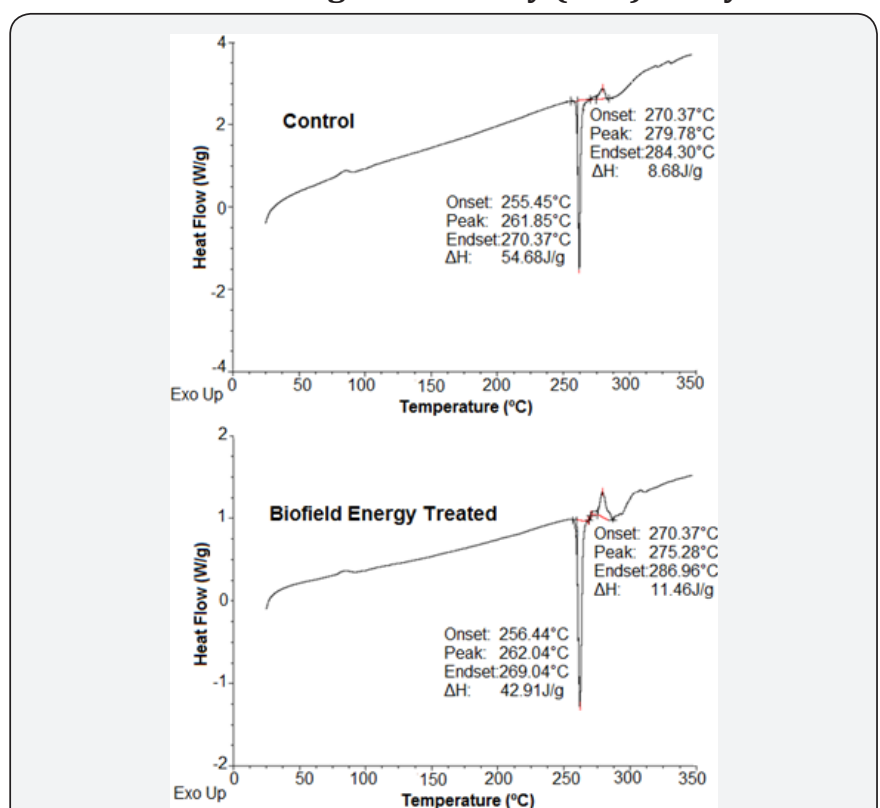

Figure 2: DSC thermograms of the control and the Biofield Energy Treated silver sulfadiazine.

Table 3: DSC data for both control and the Biofield Energy Treated samples of silver sulfadiazine. $\Delta \mathrm{H}$ : Latent heat of fusion and decomposition, *denotes the percentage change of the Biofield Energy Treated sample with respect to the control sample.

\begin{tabular}{|c|c|c|c|c|}
\hline Sample & $\begin{array}{c}\text { Melting } \\
\text { point }\left({ }^{\circ} \mathbf{C}\right)\end{array}$ & $\Delta \mathbf{H}(\mathbf{J} / \mathbf{g})$ & $\begin{array}{c}\text { Decomposition } \\
\text { temperature }\end{array}$ & $\Delta \mathbf{H}(\mathbf{J} / \mathbf{g})$ \\
\hline $\begin{array}{c}\text { Control } \\
\text { Sample }\end{array}$ & 261.85 & 54.68 & 279.78 & 8.68 \\
\hline $\begin{array}{c}\text { Biofield } \\
\text { Energy } \\
\text { Treated }\end{array}$ & 262.04 & 42.91 & 275.28 & 11.46 \\
\hline $\begin{array}{c}\% \\
\text { Change* }\end{array}$ & 0.07 & -21.52 & -1.61 & 32.03 \\
\hline
\end{tabular}

The DSC technique determines the enthalpy of the control and the Biofield Energy Treated samples, and thereby might show the glass transition temperature as well as the endothermic and exothermic events taken place during heating [48]. The DSC thermograms of the control and the Biofield Energy Treated sample showed the sharp endothermic peak at 261.85 and 
$262.04^{\circ} \mathrm{C}$, respectively (Figure 2) that is considered as their melting points. It indicated the similar melting points of both the samples; however, the latent heat of fusion $\left(\Delta \mathrm{H}_{\text {fusion }}\right)$ of the Biofield Energy Treated sample $(42.91 \mathrm{~J} / \mathrm{g}$ ) was significantly reduced by $21.52 \%$ (Table 3) compared with the control sample (54.68 J/g).

Moreover, there was an exothermic peak also observed in the thermograms of the control and the Biofield Energy Treated sample that is considered as the decomposition temperature. The analysis revealed that the decomposition temperature of the Biofield Energy Treated sample was decreased by $1.61 \%$; whereas the $\Delta \mathrm{H}_{\text {decomposition }}$ was significantly increased by $32.03 \%$, compared to the control sample (Table 3 ). Hence, it could be assumed that the Biofield Energy Treatment might disrupt the molecular chains, as well as the crystal structure of the Biofield Energy Treated silver sulfadiazine that might be responsible for the alterations in the melting temperatures and latent heat [42] compared with the control sample.

\section{Thermal Gravimetric Analysis (TGA)/ Differential Thermogravimetric Analysis (DTG)}

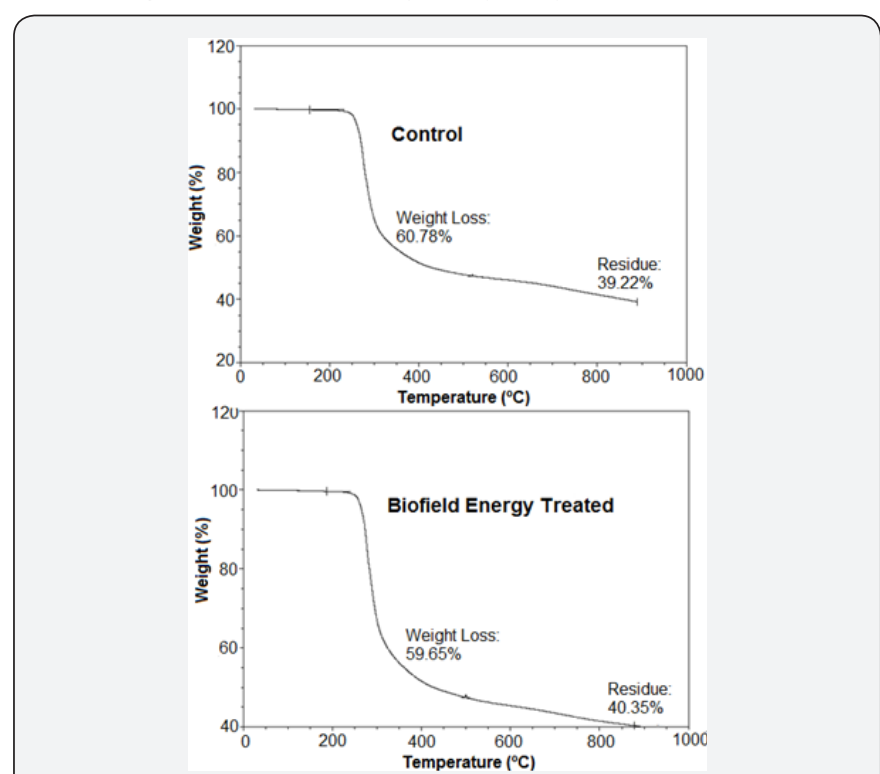

Figure 3: TGA thermograms of the control and the Biofield Energy Treated silver sulfadiazine.

The TGA thermograms were used to establish the thermal degradation profile of the samples, displayed single step thermal degradation for the control and the Biofield Energy Treated samples (Figure 3). The experimental data showed that the total weight loss due to thermal degradation of the Biofield Energy Treated sample was reduced by $1.86 \%$ in comparison to the control sample (Table 4). In response to this, the residue amount of the Biofield Energy Treated sample was observed to be increased by $2.88 \%$ compared to the control sample. Thus, the thermal degradation of the Biofield Energy Treated sample was observed to be reduced after the Biofield Energy Treatment compared with the untreated silver sulfadiazine.

The first derivative of the weight loss curve (i.e., the DTG thermogram) is used to determine the temperature points at which the weight loss is most apparent [48]. In this study, the DTG thermograms of the control and the Biofield Energy Treated sample showed a single peak (Figure 4). It was observed that the Biofield Energy Treated silver sulfadiazine showed maximum weight loss $\mathrm{T}_{\text {max }}$ at $276.78^{\circ} \mathrm{C}$, which was slightly increased by $0.94 \%$ (Table 4) in comparison to the $\mathrm{T}_{\max }$ of the control silver sulfadiazine $\left(274.21^{\circ} \mathrm{C}\right)$. Overall, the TGA/DTG study indicated that the thermal stability of the Biofield Energy Treated sample was improved compared with the control sample.

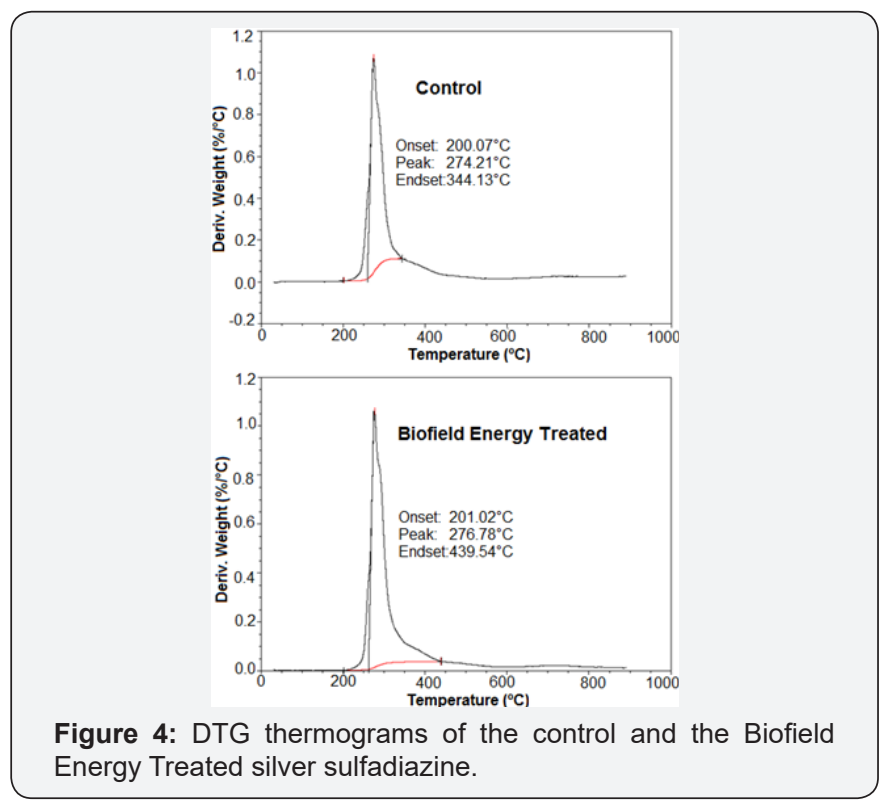

Table 4: TGA/DTG data of the control and the Biofield Energy Treated samples of silver sulfadiazine.

\begin{tabular}{|c|c|c|c|}
\hline \multirow{2}{*}{ Sample } & TGA & DTG & \\
\cline { 2 - 4 } & $\begin{array}{c}\text { Total weight loss } \\
\mathbf{( \% )}\end{array}$ & Residue \% & $\left.\mathbf{T}_{\max } \mathbf{(}^{\circ} \mathbf{C}\right)$ \\
\hline Control & 60.78 & 39.22 & 274.21 \\
\hline $\begin{array}{c}\text { Biofield Energy } \\
\text { Treated }\end{array}$ & 59.65 & 40.35 & 276.78 \\
\hline \% Change* & -1.86 & 2.88 & 0.94 \\
\hline
\end{tabular}

*denotes the percentage change of the Biofield Energy Treated sample with respect to the control sample,

$\mathrm{T}_{\max }=$ the temperature at which maximum weight loss takes place in $\mathrm{TG}$ or peak temperature in DTG.

\section{Conclusion}

The impact of the Trivedi Effect ${ }^{\circledR}$-Consciousness Energy Healing Treatment on silver sulfadiazine was significant on the crystal morphology and structure, particle size, and thermal properties. The PXRD data showed alterations in the Bragg's angles of the characteristic peaks of the Biofield Energy Treated sample along with the peak intensity in comparison to the untreated sample. The intensities of those peaks of the Biofield Energy Treated sample were altered ranging from $-75.25 \%$ to $31.21 \%$; while the crystallite sizes showed the significant alteration ranging from $-8.80 \%$ to $192.76 \%$, compared with the control sample. Moreover, the Biofield Energy Treated sample 
showed a significant increase in the average crystallite size by $64.06 \%$ compared with the untreated silver sulfadiazine sample. The particle size distribution of the Biofield Energy Treated sample also indicated significant alterations in the particle sizes after the Biofield Energy Treatment. The particle size values were reduced by $1.60 \%, 2.30 \%, 2.06 \%$, and $4.40 \%$ at $\mathrm{d}_{10}, \mathrm{~d}_{50}, \mathrm{~d}_{90}$, and D $(4,3)$, respectively compared to the control sample. Therefore, the specific surface area of the Biofield Energy Treated sample was increased by $2.61 \%$ compared to the control sample. The $\Delta \mathrm{H}_{\text {fusion }}$ of the Biofield Energy Treated silver sulfadiazine was significantly decreased by $21.52 \%$ compared with the untreated sample. Nevertheless, the $\Delta \mathrm{H}_{\text {decomposition }}$ of the Biofield Energy Treated sample was significantly increased by $32.03 \%$ compared to the control sample. The total weight loss analyzed from the TGA analysis showed $1.86 \%$ reduction in the Biofield Energy Treated sample that resulted in $2.88 \%$ increase in the residual amount in comparison to the untreated silver sulfadiazine. The DTG analysis showed $\sim 2.5^{\circ} \mathrm{C}$ increase $(0.94 \%)$ in the $\mathrm{T}_{\max }$ of the Biofield Energy Treated silver sulfadiazine sample compared with the control sample. Thus, the overall data suggests that the Trivedi Effect ${ }^{\circledR}$-Consciousness Energy Healing Treatment might generate a novel polymorph of silver sulfadiazine which would be more soluble, absorbable, and bioavailable and thermally more stable compared with the untreated sample. Hence, the Trivedi Effect $^{\circledR}$ Treated silver sulfadiazine can provide better therapeutic benefits to prevent and treat microbial infections by designing more efficacious pharmaceutical formulations.

\section{Acknowledgement}

The authors are grateful to Central Leather Research Institute, SIPRA Lab. Ltd., Trivedi Science, Trivedi Global, Inc., Trivedi Testimonials, and Trivedi Master Wellness for their assistance and support during this work.

\section{Conflict of Interest}

Authors declare no conflict of interest.

\section{References}

1. Marx J, Walls R, Hockberger R (2013) Rosen's Emergency MedicineConcepts and Clinical Practice, Volume 2, ( $8^{\text {th }}$ edn). Elsevier Health Sciences, US.

2. Dickinson SJ (1973) Topical Therapy of Burns in children with Silver Sulfadiazine. N Y State J Med 73(16): 2045-2049.

3. McDougall IA (1972) Burns and the use of Silver Sulphadiazine. Aust N Z J Surg 42(2): 174-178.

4. Nascimento EGD, Sampaio TBM (2009) Evaluation of Chitosan Gel with $1 \%$ Silver Sulfadiazine as an Alternative for Burn Wound Treatment in Rats. Acta Bras Cir 24(6): 460-465.

5. Ricketts CR, Lowbury EJ, Lawrence JC, Hall M, Wilkins MD (1970) Mechanism of Prophylaxis by silver Compounds Against Infection of Burns. Br Med J 2: 444-446.

6. Modak SM, Fox CL (1973) Binding of silver sulfadiazine to the cellular components of Pseudomonas aeruginosa. Biochem Pharmacol 22(19): 2391-2404
7. Herbert SR, Howard SC (1972) Silver Sulfadiazine: Effect on the Growth and Metabolism of Bacteria. Antimicrob Agents Chemother 2(5): $367-372$.

8. Wysor MS, Zollinhofer RE (1972) On the Mode of Action of Silver Sulfadiazine. Pathobiology 38: 296-308.

9. Fox CL, Modak SM (1974) Mechanism of Silver Sulfadiazine Action on Burn Wound Infections. Antimicrob Agents Chemother 5(6): 582-588.

10. Wasiak J, Cleland H, Campbell F, Spinks A (2013) Dressings for Superficial and Partial Thickness Burns. The Cochrane Database of Systematic Reviews 3: CD002106.

11. Trivedi MK, Mohan TRR (2016) Biofield energy signals, energy transmission and neutrinos. American Journal of Modern Physics 5(6): 172-176.

12. Trivedi MK, Branton A, Trivedi D, Nayak G, Lee AC, et al. (2016) Impact of biofield energy treated herbomineral formulation (the Trivedi Effect $^{\circledR}$ ) on mouse dendritic and splenocyte cells for modulation of pro-inflammatory cytokines. International Journal of Immunology $4(5)$ : $35-45$.

13. Trivedi MK, Branton A, Trivedi D, Nayak G, Wellborn BD, et al. (2017) Effect of the energy of consciousness (the Trivedi Effect ${ }^{\circledR}$ ) on the structural properties and isotopic abundance ratio of magnesium gluconate using LC-MS and NMR spectroscopy. Advances in Biochemistry 5(1): 7-15.

14. Trivedi MK, Branton A, Trivedi D, Nayak G, Afaganis AE, et al. (2017) An Impact of energy of consciousness (the Trivedi Effect ${ }^{\circledR}$ ) on the physicochemical, thermal, structural, and behavioral properties of magnesium gluconate. Biomedical Sciences 3(2): 42-54.

15. Rubik B, Muehsam D, Hammerschlag R, Jain S (2015) Biofield science and healing: history, terminology, and concepts. Glob Adv Health Med $4: 8-14$.

16. Barnes PM, Bloom B, Nahin RL (2008) Complementary and alternative medicine use among adults and children: United States, 2007. Natl Health Stat Report 12:1-23.

17. Koithan M (2009) Introducing complementary and alternative therapies. J Nurse Pract 5(1): 18-20.

18. Trivedi MK, Tallapragada RM, Branton A, Trivedi D, Nayak G, et al. (2015) Characterization of Physical and Structural Properties of Aluminum Carbide Powder: Impact of biofield Treatment. J Aeronaut Aerospace Eng 4(1): 142.

19. Trivedi MK, Patil S, Tallapragada RM (2013) Effect of biofield treatment on the physical and thermal characteristics of vanadium pentoxide powders. J Material Sci Eng S 11: 001.

20. Trivedi MK, Patil S, Shettigar H, Bairwa K, Jana S (2015) Spectroscopic characterization of biofield treated metronidazole and tinidazole. Med chem 5(7): 340-344.

21. Trivedi MK, Branton A, Trivedi D, Shettigar H, Bairwa K, et al. (2015) Fourier Transform Infrared and Ultraviolet-Visible Spectroscopic Characterization of Biofield Treated Salicylic Acid and Sparfloxacin. Nat Prod Chem Res 3(5): 186.

22. Branton A, Jana S (2017) The use of novel and unique biofield energy healing treatment for the improvement of poorly bioavailable compound, berberine in male Sprague Dawley rats. American Journal of Clinical and Experimental Medicine 5(4): 138-144.

23. Branton A, Jana S (2017) Effect of the biofield energy healing treatment on the pharmacokinetics of 25-hydroxyvitamin $\mathrm{D}_{3}[25(\mathrm{OH})$ $\mathrm{D}_{3}$ ] in rats after a single oral dose of vitamin $\mathrm{D}_{3}$. American Journal of Pharmacology and Phytotherapy 2(1): 11-18. 
24. Trivedi MK, Branton A, Trivedi D, Nayak G, Sethi KK, et al. (2016) Gas chromatography-mass spectrometry based isotopic abundance ratio analysis of biofield energy treated methyl-2-napthylether (Nerolin). American Journal of Physical Chemistry 5(4): 80-86.

25. Trivedi MK, Branton A, Trivedi D, Nayak G, Bairwa K, et al. (2015) Spectroscopic characterization of disodium hydrogen orthophosphate and sodium nitrate after biofield treatment. J Chromatogr Sep Tech 6(5): 282.

26. Nayak G, Altekar N (2015) Effect of biofield treatment on plant growth and adaptation. J Environ Health Sci 1: 1-9.

27. Trivedi MK, Patil S, Shettigar H, Mondal SC, Jana S (2015) Evaluation of biofield modality on viral load of Hepatitis B and C viruses. J Antivir Antiretrovir 7(3): 083-088.

28. Trivedi MK, Patil S, Shettigar H, Mondal SC, Jana S (2015) An Impact of biofield Treatment: Antimycobacterial susceptibility Potential Using BACTEC 460/MGIT-TB System. Mycobact Dis 5(4): 189.

29. Trivedi MK, Branton A, Trivedi D, Nayak G, Charan S, et al. (2015) Phenotyping and 16S rDNA analysis after biofield treatment on Citrobacter braakii: A urinary pathogen. J Clin Med Genom 3: 129.

30. Kinney JP, Trivedi MK, Branton A, Trivedi D, Nayak G, et al. (2017) Overall skin health potential of the biofield energy healing based herbomineral formulation using various skin parameters. American Journal of Life Sciences 5(2): 65-74.

31. Trivedi MK, Branton A, Trivedi D, Nayak G, Mondal SC, (2015) Effect of Biofield Treated Energized Water on the Growth and Health Status in Chicken (Gallus gallus domesticus). Poult Fish WildlSci 3: 140.

32. Trivedi MK, Branton A, Trivedi D, Nayak G, Gangwar M, et al. (2015) Agronomic characteristics, growth analysis, and yield response of biofield treated mustard, cowpea, horse gram, and groundnuts. International Journal of Genetics and Genomics 3: 74-80.

33. Trivedi MK, Branton A, Trivedi D, Nayak G, Mondal SC, et al. (2015) Evaluation of plant growth, yield and yield attributes of biofield energy treated mustard (Brassica juncea) and chick pea (Cicer arietinum) seeds. Agriculture, Forestry and Fisheries 4(6): 291-295.

34. Desktop X-ray Diffractometer “MiniFlex+” (1997) The Rigaku Journal 14: $29-36$

35. Zhang T, Paluch K, Scalabrino G, Frankish N, Healy AM, et al. (2015) Molecular structure studies of (1S,2S)-2-benzyl-2,3-dihydro-2(1Hinden-2-yl)-1H-inden-1-ol. J Mol Struct 1083: 286-299.

36. Langford JI, Wilson AJC (1978) Scherrer after sixty years: A survey and some new results in the determination of crystallite size. J Appl Cryst 11(2): 102-113
37. Trivedi MK, Sethi KK, Panda P, Jana S (2017) A comprehensive physicochemical, thermal, and spectroscopic characterization of zinc (II) chloride using X-ray diffraction, particle size distribution, differential scanning calorimetry, thermogravimetric analysis/ differential thermogravimetric analysis, ultraviolet-visible, and Fourier transform-infrared spectroscopy. International Journal of Pharmaceutical Investigation 7(1): 33-40.

38. Trivedi MK, Sethi KK, Panda P, Jana S (2017) Physicochemical, Thermal and Spectroscopic Characterization of Sodium Selenate Using XRD, PSD, DSC, TGA/DTG, UV-vis, and FT-IR. Marmara Pharmaceutical Journal 21(2): 311-318.

39. Inoue M, Hirasawa I (2013) The relationship between crystal morphology and XRD peak intensity on $\mathrm{CaSO}_{4} \cdot 2 \mathrm{H}_{2} \mathrm{O}$. J Crystal Growth 380: 169-175.

40. Raza K, Kumar P, Ratan S, Malik R, Arora S (2014) Polymorphism: The phenomenon affecting the performance of drugs. SOJ Pharm Pharm Sci 1: 10 .

41. Brittain HG (2009) Polymorphism in pharmaceutical solids in Drugs and Pharmaceutical Sciences, volume 192, ( $2^{\text {nd }}$ edn). Informa Healthcare USA, Inc., New York.

42. Censi R, Martino PD (2015) Polymorph Impact on the Bioavailability and Stability of Poorly Soluble Drugs. Molecules 20(10): 18759-18776.

43. Blagden N, de Matas M, Gavan PT, York P (2007) Crystal Engineering of Active Pharmaceutical Ingredients to improve Solubility and dissolution Rates. Adv Drug Deliv Rev 59(7): 617-630.

44. Zhao Z, Xie M, Li Y, Chen A, Li G, et al. (2015) Formation of curcumin nanoparticles via solution-enhanced dispersion by supercritical CO2. Int J Nanomedicine 10: 3171-3181.

45. Loh ZH, Samanta AK, Heng PWS (2015) Overview of milling techniques for improving the solubility of poorly water-soluble drugs. Asian J Pharm 10: 255-274.

46. Khadkaa P, Roa J, Kim H, Kim I, Kim JT, et al. (2014) Pharmaceutical particle Technologies: An Approach to improve Drug Solubility, Dissolution and Bioavailability. Asian J Pharm 9(6): 304-316.

47. Hu J, Johnston KP, Williams RO (2004) Nanoparticle engineering processes for enhancing the dissolution rates of poorly water-soluble drugs. Drug Dev Ind Pharm 30(3): 233-245.

48. Jodar KSP, Balcao VM, Chaud MV, Tubino M, Yoshida VMH, et al. (2015) Development and Characterization of a Hydrogel Containing Silver Sulfadiazine for Antimicrobial Topical Applications. J Pharm Sci 104(7): 2241-2254.

\section{Your next submission with Juniper Publishers} will reach you the below assets

- Quality Editorial service

- Swift Peer Review

- Reprints availability

- E-prints Service

- Manuscript Podcast for convenient understanding

- Global attainment for your research

- Manuscript accessibility in different formats

( Pdf, E-pub, Full Text, Audio)

- Unceasing customer service

Track the below URL for one-step submission

https://juniperpublishers.com/online-submission.php 